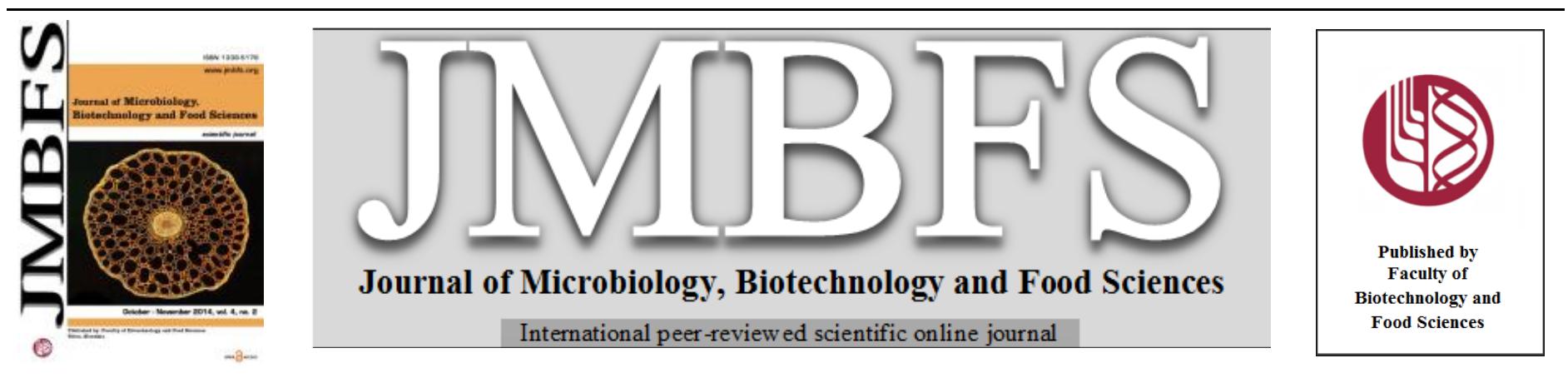

\title{
THE MOST IMPORTANT POLLUTANTS OF EASTERN SLOVAKIA WATERS
}

\section{Tatiana Hrušková}

Address(es): RNDr. Tatiana Hrušková,

The University of Veterinary Medicine and Pharmacy, Institute of Medical Chemistry, Komenského 73, 04181 Košice, Slovak Republic, +421915984616.

*Corresponding author: tatiana.hruskova@uvlf.sk

doi: 10.15414/jmbfs.2014.4.2.112-116

\section{ARTICLE INFO}

Received 6. 5. 2014

Revised 31. 7. 2014

Accepted 20. 8. 2014

Published 1. 10. 2014

\section{Review}

open 2 access

\begin{abstract}
As the area of the Slovak Republic is $49,036 \mathrm{~km}^{2}$, there are many potential contaminants that can affect its population. In the socialist era the town of Strážske located in the Košice Municipal Region was the centre of production of polychlorinated biphenyls (PCB) inter alia and nowadays about 3,500 metric tonnes of PCB are persisting there and present the greatest PCB environmental risk in the central Europe. The heavy metal contamination in Slovakia is caused by the natural background as well as by the former mining activities. In Slovakia there are about 17 thousand old mining works, i.e. adits, stocks, and impoundments. Contamination of the ground and surface waters in the Spiš-Gemer Ore Mountain (SGOM) area is caused by mine drainage. Arsenic, antimony, copper, mercury, cadmium, and zinc are the main pollutants of natural waters. All contaminated areas are currently monitored according to the national and EU legislation and nutrient load reduction programmes. As a result of this the level of inorganic and organic micropollutants in surface water and water reservoirs will be reduced together with the negative impact of water pollution on the environment in Eastern Slovakia region.
\end{abstract}

Keywords: Pollution, PCB, POPs, heavy metals, sediments, groundwater, surface water

\section{INTRODUCTION}

Eastern Slovakia consists of two regions, Prešov Region $\left(8,974 \mathrm{~km}^{2}, 18.3 \%\right.$ of the Slovak Republic territory) in the north and Košice Region $\left(6,755 \mathrm{~km}^{2}\right.$, $13.8 \%$ of Slovakia territory). On this not so large area, there are located three most contaminated Slovak villages - Rudník, Rudňany, and Zlatá Idka (Košice Region) as well as three least contaminated villages - Ruská Bystrá (Košice Region), Nová Sedlica and Obručné (Prešov Region) - Table 1, Table 2, Table 3, Map 1 (Rapant et al., 2001; Rapant et al., 2013; Cvečková et al., 2013).

Map 1 The most polluted (red colour) and the least polluted (blue colour) villages of Eastern Slovakia

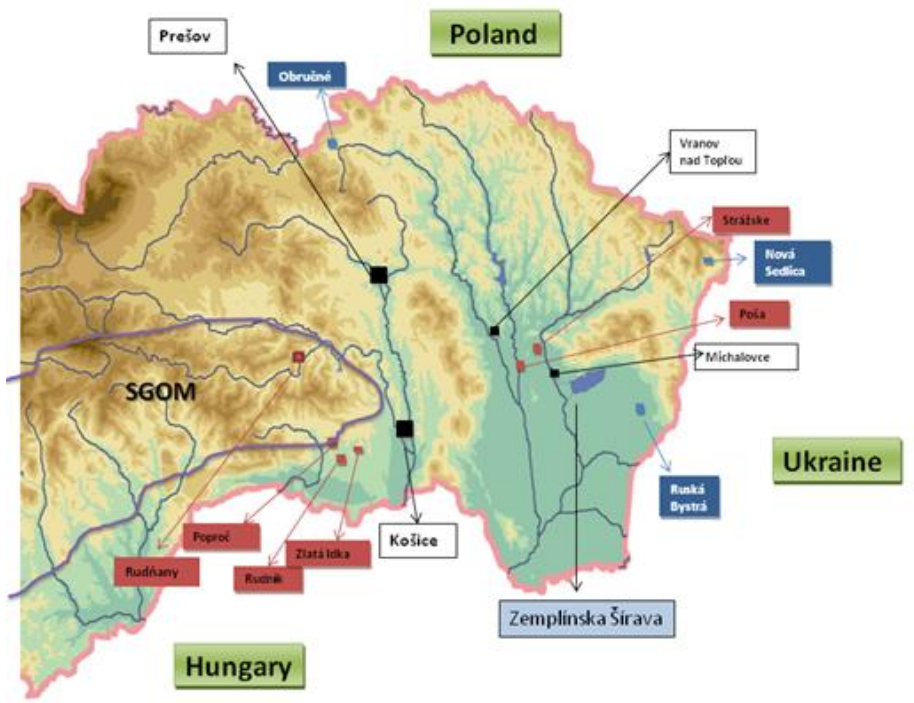

Legend: SGOM - Spiš-Gemer Ore Mountain Source: own figure

Most of the contamination of the Eastern Slovakia area is caused by anthropogenic activities, particularly by industrial activities during the socialist era, for example polychlorinated biphenyls, PCB pollution in the Zemplín informal region, As and $\mathrm{Zn}$ contamination in Poša due to ash impoundment, and also combined geological and anthropological contamination, such as mine drainage from old Spiš-Gemer mining works, or mostly anthropogenic contamination due to illegal stocks along the Hornád river banks.

We focused on the research of the most contaminated areas of eastern Slovakia, the type and extent of pollution and the potential impact of the contamination on public health in this region. We also tried to compare the previous situation with the recent results. Table 1 shows that inhabitants of areas with the most polluted water are exposed to the highest risk, indicated by the total environmental risk index $\mathrm{I}_{\mathrm{ER}}$, which takes into consideration risks related not only to surface and ground water but also to soil contamination. The index calculated for villages with most contaminated water is considerably higher than in those with lower level of contamination. The risk is reflected in higher mortality rates and increased incidence of diseases, such as diabetes mellitus, endocrinopathies, mental disorders and malformations compared to other Slovak regions Cicmanová and Baláž, 2007). 
Table 1 The level of contamination of the geological branch of the environment in Slovak villages (expressed by an index of environmental risk of contamination of the geological environment) - highlited - villages in the Eastern Slovakia

20 the least contaminated villages

\begin{tabular}{|c|c|c|c|c|c|}
\hline Village name & Region name & $I_{E R}$ & $I_{\text {ERuw }}$ & $I_{E R s}$ & $I_{E R r s}$ \\
\hline Ruská Bystrá & Sobrance & 0,06 & $\mathbf{0 , 0 3}$ & $\mathbf{0 , 0 8}$ & 0,06 \\
\hline Nová Sedlica & Snina & 0,06 & 0,04 & 0,10 & $\mathbf{0 , 0 3}$ \\
\hline Obručné & Stará L'ubovňa & 0,06 & 0,01 & $\mathbf{0 , 0 4}$ & $\mathbf{0 , 1 3}$ \\
\hline Ivanovce & Trenčín & 0,07 & 0,16 & 0,06 & 0,00 \\
\hline Inovce & Sobrance & $\mathbf{0 , 0 8}$ & $\mathbf{0 , 0 3}$ & $\mathbf{0 , 1 1}$ & 0,09 \\
\hline Sulín & Stará L'ubovňa & $\mathbf{0 , 0 8}$ & $\mathbf{0 , 0 7}$ & $\mathbf{0 , 0 7}$ & 0,09 \\
\hline Mníšek nad Popradom & Stará Lubovňa & 0,09 & 0,08 & 0,14 & $\mathbf{0 , 0 5}$ \\
\hline Petrovce & Sobrance & 0,09 & $\mathbf{0 , 0 2}$ & 0,06 & $\mathbf{0 , 2 0}$ \\
\hline Nová Bošáca & Nové Mesto nad Váhom & 0,10 & 0,05 & 0,12 & 0,13 \\
\hline L'utov & Bánovce nad Bebravou & 0,11 & 0,26 & 0,04 & 0,02 \\
\hline Vojnatina & Sobrance & 0,12 & $\mathbf{0 , 2 5}$ & $\mathbf{0 , 0 0}$ & 0,09 \\
\hline Ležiachov & Martin & 0,14 & 0,13 & 0,18 & 0,10 \\
\hline Ruská Vol’a nad Popradom & Stará Lubovňa & 0,14 & $\mathbf{0 , 2 0}$ & 0,11 & $\mathbf{0 , 1 0}$ \\
\hline Lednica & Púchov & 0,14 & 0,14 & 0,18 & 0,10 \\
\hline Kolibabovce & Sobrance & 0,15 & $\mathbf{0 , 2 5}$ & $\mathbf{0 , 0 1}$ & $\mathbf{0 , 1 8}$ \\
\hline Krivoklát & Ilava & 0,15 & 0,03 & 0,30 & 0,11 \\
\hline Daletice & Sabinov & 0,15 & $\mathbf{0 , 2 3}$ & 0,19 & 0,04 \\
\hline Šiatorská Bukovinka & Lučenec & 0,16 & 0,38 & 0,06 & 0,04 \\
\hline Štvrtok & Trenčín & 0,16 & 0,38 & 0,02 & 0,09 \\
\hline Haluzice & Nové Mesto nad Váhom & 0,17 & 0,41 & 0,03 & 0,06 \\
\hline Moškovec & Turčianske Teplice & 0,17 & 0,24 & 0,22 & 0,04 \\
\hline
\end{tabular}

\begin{tabular}{|c|c|c|c|c|c|}
\hline \multicolumn{6}{|c|}{20 the most contaminated villages } \\
\hline Rudník & Košice-okolie & 156,74 & 2,07 & 4,18 & 463,97 \\
\hline Rudňany & Spišská Nová Ves & 156,68 & 2,60 & 41,85 & 425,59 \\
\hline Zlatá Idka & Košice-okolie & 150,26 & 2,15 & 11,96 & 436,68 \\
\hline Smolník & Gelnica & 146,18 & 30,01 & 15,53 & 393,00 \\
\hline Matejovce & Spišská Nová Ves & 136,84 & 2,65 & $\mathbf{3 0 , 5 0}$ & 377,38 \\
\hline Liptovská Sielnica & Liptovský Mikuláš & 134,34 & 395,65 & 0,59 & 6,78 \\
\hline Poproč & Košice-okolie & 131,13 & 7,57 & 10,53 & 375,31 \\
\hline Liptovský Trnovec & Liptovský Mikuláš & 130,16 & 382,48 & 0,83 & 7,16 \\
\hline Smolnícka Huta & Gelnica & 118,97 & 24,32 & 17,97 & 314,62 \\
\hline Švedlár & Gelnica & 100,71 & 8,12 & 33,05 & 260,95 \\
\hline Teplička & Spišská Nová Ves & 99,79 & $\mathbf{0 , 0 2}$ & 278,08 & 21,28 \\
\hline Liptovské Matiašovce & Liptovský Mikuláš & 98,16 & 293,55 & 0,67 & 0,28 \\
\hline Hnilčík & Spišská Nová Ves & 98,12 & 0,44 & 270,35 & 23,56 \\
\hline Dúbrava & Liptovský Mikuláš & 91,98 & 146,34 & 4,69 & 124,92 \\
\hline Lazisko & Liptovský Mikuláš & 90,95 & 136,83 & 4,70 & 131,33 \\
\hline Liptovská Štiavnica & Ružomberok & 86,38 & 245,73 & 2,20 & 11,21 \\
\hline Červenica & Prešov & 79,64 & 53,88 & 0,26 & 184,78 \\
\hline Odorín & Spišská Nová ves & 72,02 & 0,46 & 12,28 & 203,33 \\
\hline Malachov & Banská Bystrica & 70,61 & 0,86 & 126,37 & 84,60 \\
\hline
\end{tabular}

Legend: $\mathrm{I}_{\mathrm{ERuw}}, \mathrm{I}_{\mathrm{ERs}}, \mathrm{I}_{\mathrm{ERrs}}, \mathrm{I}_{\mathrm{ER}}$ - indexes of environmental risk for ground waters, soils and river sediments and the summary of geological branches

Source: Rapant et al., 2001 
Table 2 The most polluted Slovak regions (Eastern Slovakia regions - blue colour)

\begin{tabular}{|c|c|c|c|c|c|}
\hline \multicolumn{2}{|c|}{ Polluted regions } & $\begin{array}{l}\text { Extent } \\
{\left[\mathrm{km}^{2}\right]}\end{array}$ & $I_{E R}$ & $\begin{array}{l}\text { Major } \\
\text { source of } \\
\text { pollution }\end{array}$ & Ground water \\
\hline \multicolumn{2}{|c|}{ 1. SPIŠ - GEMER } & 910 & 20,7 & $\mathbf{G}$ & As, Sb, Fe, Mn \\
\hline \multicolumn{2}{|c|}{ 2. L. Mikuláš - Brezno } & 650 & 14,5 & $\mathrm{G}$ & $\mathrm{As}, \mathrm{Sb}, \mathrm{SO}_{4}$ \\
\hline \multicolumn{2}{|c|}{ 3. B. Štiavnica - Krupina } & 400 & 9,0 & G & $\mathrm{Fe}, \mathrm{Mn}, \mathrm{SO}_{4}, \mathrm{~N}$ \\
\hline \multicolumn{2}{|c|}{ 4. Upper Nitra } & 320 & 8,1 & G-A & As, Fe, Mn, NC \\
\hline \multicolumn{2}{|c|}{ 5. MOLDAVA nad BODVOU } & 150 & 20,3 & G-A & $\mathrm{Mn}, \mathrm{NO}_{3}, \mathrm{Fe}$ \\
\hline \multicolumn{2}{|c|}{ 6. B. Bystrica - Zvolen } & 280 & 13,8 & $\mathrm{G}-\mathrm{A}$ & $\mathrm{Sb}, \mathrm{Cd}, \mathrm{As}$ \\
\hline \multicolumn{2}{|c|}{ 7. Bratislava - Senec - Pezinok } & 220 & 7,1 & G-A & $\mathrm{NO}_{3}, \mathrm{SO}_{4}, \mathrm{Fe}, \mathrm{I}$ \\
\hline \multicolumn{2}{|c|}{ 8. Galanta - Sered' } & 1100 & 6,9 & $\mathrm{~A}$ & $\mathrm{NO}_{3}, \mathrm{SO}_{4}, \mathrm{Mn}$, \\
\hline \multicolumn{2}{|c|}{ 9. Nitra - Šurany } & 290 & 7,0 & $\mathrm{~A}$ & $\mathrm{NO}_{3}, \mathrm{Mn}, \mathrm{NH}_{4}$ \\
\hline \multicolumn{2}{|c|}{ 10. Levice - Želiezovce } & 350 & 4,3 & $\mathrm{~A}$ & $\mathrm{NO}_{3}, \mathrm{Mn}, \mathrm{Fe}$ \\
\hline \multirow{2}{*}{\multicolumn{2}{|c|}{$\begin{array}{l}\text { 11. TREBIŠOV - K. CHLME } \\
\text { 12. SOUTH KOŠICE }\end{array}$}} & 1100 & 4,3 & $\mathbf{A}$ & $\mathrm{NO}_{3}, \mathrm{TDS}, \mathrm{Cl}$, \\
\hline & & 150 & 8,2 & $\mathbf{A}$ & $\mathrm{NO}_{3}, \mathrm{Mn}$, \\
\hline \multicolumn{2}{|c|}{ 13. NORTH KOŠICE } & 140 & 6,5 & $\mathbf{A}$ & $\mathrm{Mn}, \mathrm{Fe}, \mathrm{NO}_{3}$ \\
\hline \multicolumn{2}{|c|}{ 14. Stupava - Malacky } & 300 & 6,8 & $\mathrm{~A}$ & $\mathrm{Fe}, \mathrm{Mn}, \mathrm{NO}_{3}, \mathrm{~S}$ \\
\hline \multicolumn{6}{|c|}{$\begin{array}{l}\text { Legend: } \mathrm{I}_{\mathrm{ER}}-\text { indexes of environmental risk, level of contamination: ++++ very high, }+++ \text { high } \\
\mathrm{A} \text { - anthropogenic, } \mathrm{G}-\text { geogenic, } \mathrm{G}-\mathrm{A} \text { - geogenic-anthropogenic major source of pollution } \\
\text { Source: Rapant et al., } 2001\end{array}$} \\
\hline \multicolumn{6}{|c|}{ Table 3 Contaminated Eastern Slovakia areas and their major pollutants } \\
\hline $\begin{array}{l}\text { Burdened } \\
\text { area }\end{array}$ & $\begin{array}{l}\text { Territory } \\
\text { area } \\
\text { in } \mathbf{k m}^{2}\end{array}$ & Population & Pollutants & $\begin{array}{r}\text { Bu } \\
\text { territo } \\
\text { the } \\
\text { munici } \\
\text { Propo } \\
\end{array}$ & $\begin{array}{l}\text { dened } \\
\text { ies within } \\
\text { cope of } \\
\text { al regions } \\
\text { tion in \% } \\
\end{array}$ \\
\hline $\begin{array}{l}\text { Rudňany } \\
\text { - Gelnica }\end{array}$ & 357 & 52000 & $\begin{array}{l}\mathrm{Hg}, \mathrm{Cu} \\
\mathrm{Pb}, \mathrm{As}, \\
\mathrm{Zn}, \mathrm{Cd} \\
\mathrm{SO}_{2}, \mathrm{O}_{\mathrm{x}}\end{array}$ & $\begin{array}{l}\text { Košic } \\
\text { Prešc }\end{array}$ & $\begin{array}{l}-95 \% \\
-\quad 5 \%\end{array}$ \\
\hline $\begin{array}{l}\text { Košice - } \\
\text { Prešov }\end{array}$ & 1044 & 425000 & $\begin{array}{l}\mathrm{SO}_{2}, \mathrm{NO}_{\mathrm{x}} \\
\mathrm{Mg}, \mathrm{Fe} \\
\mathrm{Mn}, \mathrm{Cr}\end{array}$ & $\begin{array}{l}\text { Košic } \\
\text { Prešc }\end{array}$ & $\begin{array}{l}-81 \% \\
-19 \%\end{array}$ \\
\hline Zemplín & 1040 & 173000 & $\begin{array}{l}\mathrm{SO}_{2}, \mathrm{NO}_{\mathrm{x}} \\
\mathrm{F}, \mathrm{NH}_{3} \\
\text { organic } \\
\text { pollutants }\end{array}$ & $\begin{array}{l}\text { Koši } \\
\text { Prešc }\end{array}$ & $\begin{array}{l}-83 \% \\
-17 \%\end{array}$ \\
\hline
\end{tabular}

Source: Škultéty, 2008

Graph 1 Production of PCB of particular states in metric tons during the second half of the $20^{\text {th }}$ century

\section{Production PCB of particular states in tonnes}

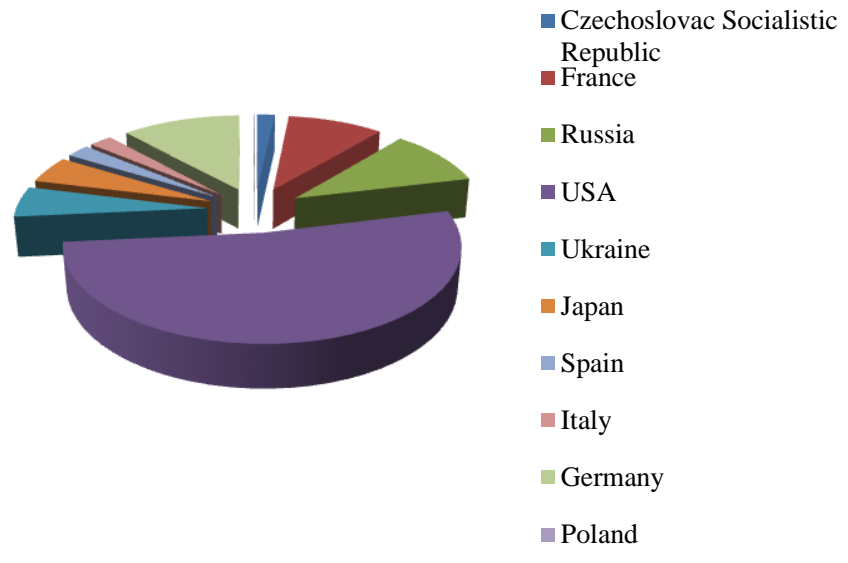

Polychlorinated biphenyls are organic compounds which belong to persisten organic pollutants - POPs, capable of persisting in the environment for a long period of time as well as of continuous permanent transport and bioaccumulation. PCBs are synthetic chemical compounds of chlorine attached to biphenyl, which is a molecule composed of two benzene rings. Their stability depends on the chlorination level. Increasing chlorination is associated with decreasing biodegradation. Biodegradation of tetrachlorinated or higher chlorinated biphenyls is very slow but other degradation methods are unknown. Nowadays acute toxicity of commercial PCBs is improbable but chronic toxicity caused by their long lasting bioaccumulation potential presents considerable risk for humans and animals particularly due to carcinogenicity of these compounds. Tests conducted in 1978, showed increased incidence of cancer caused by PCB exposure (Danielovič et al., 2009).

PCBs were used all over the word in various industrial branches including hydraulic liquids, condenser fillings, mechanical lubricants, dye additives, paints manufacturing and cosmetics industry, for example in lipsticks - Graph 1.

They can be found everywhere, in soil, air, ground and surface waters, can penetrate through phytoplankton into fish and other water fauna and become the source of PCBs in the food chain. Wildlife and domestic animals in endangered areas, mostly fish in polluted water, are important sources of PCBs that can reach humans primarily by the alimentary way.

Source: Danielovič et al., 2009

\section{Affected areas}

\section{Strážske and its surroundings - Zemplín}

Zemplín, the informal region located in Košice Region, is one of the most contaminated areas in Europe. Although the toxic character of PCBs was acknowledged in the seventies of the last century, they were produced in the former Czechoslovak Socialist Republic as Delor, Hydelor and Delotherm from 1959 till 1984 in the Chemko chemical factory in Strážske in the amount of about 21,500 metric tons of PCB products (Danielovič et al., 2009). Thousands of tons of PCBs were deposited in the Chemko plant area but the whole region is still contaminated. PCB pollution in Zemplín exceeds 15-20 times the mean level of PCBs in non-contaminated Slovak regions. Zemplín area, including water reservoir Zemplínska Šírava with the area of $33 \mathrm{~km}^{2}$, the Strážske wastewater canal and the Laborec river are strongly polluted by PCBs which, because of their low solubility in water, are deposited in sludge and bottom sediments (Danielovič and Hecl, 2012; Table 2).

As much as $76.8 \%$ of fish tissue samples from the above location exceed the allowed PCB limits, while of all samples collected in Košice and Trebišov areas, namely from polluted rivers Bodrog, Latorica, Tisa, and Hornád, only $8.3 \%$ exceeded the limit (Danielovič and Hecl, 2012). The wildlife fish are the most polluted food. The highest proportion of PCB accumulates in fatty tissues. High PCB levels damage the thyroid gland, cause skin disorders, functional disorders of the liver and the immune system, eye irritation, loss of memory, depression, impotence, hearing defects and tooth enamel damage (Zmetáková and Šalgovičová, 2006 a, c; Jurečková et al., 2010; Kijovská, 2013).

\section{ARSENIC, ZINC, AND ANTIMONY CONTAMINATION}

Arsenic - a metal toxic to living organisms, classified as carcinogen, is present only in one isotope modification and can be found in nature in oxidation states - 
$3,0,3$, and 5. Compounds with arsenic in the +3 oxidation state are the most toxic to humans as well as the inorganic form of As. Arsenic toxicity increases with its solubility in water (Langer et al., 2007; Fl'aková et al., 2009; Ženišová et al., 2009).

The natural presence of As in water background is about $2.6 \mu \mathrm{g} / \mathrm{L}$ and it can be found in sludges, bottom sediments, and impoundments. Increased levels of arsenic are mostly caused by human activities. Metal purification and fossil fuel combustion can be important sources of As pollution. Most frequently, food and water are the most important sources of As for humans and animals. Comparison of various food commodities showed that the highest As levels were found in the Košice Region (Langer et al., 2007)

\section{Affected areas}

\section{Poša}

Near the little village Poša in the Vranov nad Topl'ou area, there is a big source of arsenic in the form of impoundment formed in 1977 by the power station mostly for the storage of ash, which was produced during fossil fuel combustion. The upper section of Kyjov brook flows through this impoundment and empties to Ondava river (Strnadová et al., 2003). Arsenic contamination of this area reported before 1995 constituted one of the biggest environmental burdens in Slovakia.

The total As content in Kyjov brook ranges between $>300$ and $11,000 \mu \mathrm{g} / \mathrm{L}$. In 2005 the level of total arsenic in Kyjov brook was 1,780 $\mu \mathrm{g} / \mathrm{L}$, and in the Ondava river, at its junction with Kyjov brook it reached $27 \mu \mathrm{g} / \mathrm{L}$. Increased level of arsenic in comparison with its natural background in this area $(2.6 \mu \mathrm{g} / \mathrm{L})$ was detected as far as $55 \mathrm{~km}$ down the river of the impoundment, at the confluence of Ondava and Bodrog rivers (Strnadová et al., 2003).

Certain proportion of arsenic in sediments occurs in an easily soluble form $(6.62 \%)$, the remaining portion is bound to Fe and Mn oxides, and also to zinc which was present along with arsenic also in increased concentrations (Hiller et al., 2009).

\section{SGOM - Poproč}

High concentrations of As and Sb are found mostly in metal deposits, particularly in old mining impoundments. Presence of $\mathrm{Sb}$ is characteristic for Slovakia with regard to its rock bed (Sb sulphides). Increased level of antimony causes problems from the point of view of ensuring quality of drinking water because the processes of treatment of Sb-containing water that must be used to ensure drinking water quality are quite complicated. Similar applies to As-contaminated water (Jankulár et al., 2009).

Poproč village is located below one of several Sb deposits, the impoundment of which was the biggest Sb source in $19^{\text {th }}$ century. Both lateral tributaries of the Olšava river were monitored because of the massive pollution by several old mining works in the area surrounding Poproč.

The most negative impact on water quality in terms of As content is attributed to mining waters from the adit named Agnes, with As level reaching 2,400 $\mu \mathrm{g} / \mathrm{L}$ The highest level of Sb $(750 \mu \mathrm{g} / \mathrm{L})$ was identified in the adit Anna (Ilavský and Barloková, 2003; Ursíniová, 2011).

\section{SGOM - Rudník, Rudňany, Zlatá Idka}

As for geological contamination of the Slovak environment (expressed by indexes of environmental risk of geological contamination), three villages Rudník, Rudňany, and Zlatá Idka belong to the most contaminated of all (Table $1,2,3)$. They are located in the SGOM area and the contamination is caused by the location and old mining ballast. Increased As and Sb levels in water were detected there, highly exceeding the background levels of ground as well as of surface waters - Map 1, (Fl'aková et al., 2009).

The concentrations of $\mathrm{Sb}$ and also As were increased particularly below the village Zlatá Idkae, where mining waters flowed into the Ida River and unfavourably affected water quality. The Ida River flows to Bukovec wate supply reservoir - one of the most important drinking water sources for Košice and the surrounding area (Cicmanová and Baláž, 2007; Ženišová et al., 2009. Increased levels of $\mathrm{Sb}$ were detected also in an individual source of drinking water, the well supplying drinking water to two houses in the village Zlatá Idka. The results showed that the level of SB exceeded ten-fold the limit specified by the Regulation of the government of the SR No. 496/2010 Coll. This water is used for drinking, watering and feeding of domestic animals, which can contribute to the cumulative risk resulting from the presence of Sb (EWC Inc. 2014)

\section{OTHER HEAVY METALS CONTAMINATION}

As a result of heavy metal pollution, natural waters are not able to achieve thei previous quality, lose their ability of self purification including removal of organic pollutants. Heavy metals have cumulative ability resulting in their increased concentration in water systems and sediments, especially at places with low flow rates (Rapant et al., 2009). The sources of contamination of surface and ground water include also waste waters and their treatment and re-use of municipal sludge for manuring. This material contains far more heavy metals and other trace elements than artificial manures (Sasáková et al., 2006).

\section{Affected areas}

\section{SGOM region}

In addition to $\mathrm{As}$ and $\mathrm{Sb}$, which pollute the $\mathrm{SGOM}$ region, there are other heavy metals which contribute to the already bad situation regarding environmental quality and public health in the monitored area (Table 1, 2, 3). The whole surroundings of the SGOM are polluted with heavy metals due to the natural background of the mentioned area which is composed of silica-siderite-sulphide minerals: jamesonite $(\mathrm{Pb}, \mathrm{Fe}, \mathrm{Sb})$, chalcopyrite, arsenopyrite, sphalerite $(\mathrm{Fe}, \mathrm{Cu}$, Zn, As, Pb, Fe) (Fl'aková et al., 2009).

Ground waters are qualitatively and quantitatively affected by mining activities, if they are in contact with mine drainage. Water can be polluted by point and non-point sources. The waste dumps, impoundments and mine drainage are considered to be point sources of pollution, while the areas of high dust fall rate and fly-ash deposit are considered non-point sources. Heavy metals are the most frequent pollutants of ground waters (Cicmanová and Baláž, 2007).

The content of $\mathrm{As}, \mathrm{Al}, \mathrm{Fe}$, and $\mathrm{Mn}$ in ground water in the SGOM region was also increased. Total mineralisation of mine drainage in SGOM ranged in the interval 64 mg/L - 2.384 mg/L (Hudáček et al., 2000; Fargašová, 2009).

The quality of surface water in the monitored area was affected by heavy metals brought by Rudník and Slovinský brooks into the Hornád river. Water in Rudník brook was contaminated with $\mathrm{Cu}, \mathrm{Hg}$, and $\mathrm{Zn}$ and that in Slovinský Brook by $\mathrm{Hg}, \mathrm{Cu}$, and $\mathrm{Pb}$, all of them elements affecting very unfavourably the water quality. In Krompachy area Hornád river is polluted with $\mathrm{Cd}, \mathrm{Pb}$, As, and $\mathrm{Ni}$. In the Smolník area the impact of Smolník brook deteriorates the water quality of the Hnilec river due to heavy metal contamination with the consequent $\mathrm{pH}$ decrease until it joins Ružín reservoir, where the pollutants accumulate in sediments which then serve as sources of heavy metals (Cicmanová and Baláž 2007) and other pollutants, such as PCBs and POPs (Fl'aková et al., 2011 a, b).

\section{CONCLUSION}

The overall contamination in the Eastern Slovakia region is currently high and the anthropogenic contaminants have an adverse impact on public health. The mean lifespan of humans in the most contaminated villages has shortened by about 3-5 years and the incidence of various diseases increased in them 2-5 times in comparison with less polluted villages. It was observed that inhabitants living in a polluted location for a long period of time exhibit worsened health indicators particularly due to bioaccumulation which is the worst and the most dangerous attribute of all monitored pollutants (Rapant et al., 2001).

Repeated results of PCB pollution studies in the Zemplín region proved that despite the fact that $\mathrm{PCB}$ production stopped 25 years ago, PCB presence can still be identified in all samples. In the period of 2001-2006, 21.6\% of the total of 3,206 samples showed a decrease in the level of examined pollutants. Particularly fish bodies containing With regard to PCB contamination in the Zemplín region fish were the most important source (Šutriepka et al., 2006; Dercová et al., 2007 Tatarková et al., 2010). Because of high PCB content in fish tissues in the concerned area, fishing was banned in the entire area of Zemplínska Śrava (Zmetáková and Šalgovičová, 2006 b). Obviously, it is not a systemic solution to the current situation. It is necessary to strictly restrict the use of PCB materials to decrease its content in the environment, although it will be a very long process requiring introduction of new progressive industry technologies (Dercová et al. 2007). The Chemko plant, as the former producer of PCBs, participates in the Alternative PCB Destruction Project (under the sponsorship of UNIDO and the World Bank Environmental Fund) with the objective to dispose of all toxic waste stored in its area. Full decontamination and certainly continuous monitoring of the affected area is inevitable to prevent pollution spreading. According to the approved Programme Declaration of the Government of August 2006, one of the government environmental priorities is remedying environmental burdens which are considered serious environmental debt (KOŠICE REGION, 2007; SEA, 2010; WRI, 2012).

Considering the danger to human health resulting from any environmenta contamination existing today and in the future, we should make every effort to eliminate or at least alleviate the outcomes of old environmental burdens resulting from anthropogenic activities, and limit to a minimum the impacts of geogenic contamination. The Report on the waste management in the Kosice region in the years $2011-2015$, and also in 2009, indicated that the limits set for surface waters, for example at Hornád monitoring site, were exceeded with respect to parameters $\mathrm{Cu}, \mathrm{Zn}, \mathrm{Cd}, \mathrm{Ni}, \mathrm{Hg}, \mathrm{Pb}, \mathrm{As}$ and $\mathrm{Sb}$.

According to the Systematic identification of contaminated sites published in 2010, following the update of results from 2009, 27 sites with environmental burden, 83 with probable environmental burden, 81 decontaminated and 44 revitalised sites existed in the Kosice region. Seven of them were high-hazard sites, most of them in Michalovce district, involving particularly waste dumps 
and sludge beds. The state remediation programme enrolled 15 sites - landfills and waste storage sites (SEA, 2013).

In the Košice region, only $60.36 \%$ of municipalities are connected to the public water supply system, i. e. use regularly monitored water. The rest of the population obtains water from individual sources that may not have optimum quality and may affect negatively the health of consumers.

It is essential to monitor all contaminated sites, gradually eliminate the old burdens and prevent development of new ones. Legislative changes, particularly those regarding control of individual sources utilised as sources of drinking waters, would be of great help.

Acknowledgement: This study was financed by the project KEGA No.020UVLF-4/2012 (Slovak Republic).

\section{REFERENCES}

CICMANOVÁ, S., BALÁŽ, P. 2007. Historical mining ores and quality of the natural environment around the village Zlatá Idka. Podzemná voda, 13(1), 89-99. CVEČKOVÁ, V., FAJČÍKOVÁ, K., RAPANT, S. 2013. Geological structure diversity and its response in public health in Slovak republic. (in Slovak) Geochemistry (Proceedings of the Conferences, symposia, seminars) Bratislava : SGIDS, 23-26.

DANIELOVIČ, I., HECL, J. 2012. Polychlorinated biphenyls and heavy metals in soils of central and southern Zemplin regions. (in Slovak). Enviromagazín, 5, 18-19.

DANIELOVIČ, I., HECL, J., MATI, R. 2009. Polychlorinated biphenyls and their content in the environment of the region Zemplín: Information publication. (in Slovak). RESULT : Košice, 28 p.

DERCOVÁ, K., SEJÁKOVÁ, Z., SKOKANOVÁ, M., BARANČÍKOVÁ, G. MAKOVNÍKOVÁ, J., RŮŽIČKA, J. 2007. Using of organo-mineral complex for bioremediation contaminated soils, Chemické Listy, 101, 799-806.

EASTERN WATER COMPANY Inc. 2014. Sample test report No 290. (in Slovak). Specialized laboratory of waters. Workstation Kokšov-Bakša.

FARGAŠOVÁ, A. 2009. Metal pollution in Slovakia. (in Slovak). EnviroEdu. $1-16$,

<http://www.enviroedu.sk/database/environmentalne_problemy/znecistenie_kovmi_na_slovensku/En viro-edu_4013_Znecistenie_kovmi_na_Slovensku.pdf >

FLAKOVÁ, R., ŽENIŠOVÁ, Z., JAŠOVÁ, I., KRČMÁŘ， D. 2009. Contamination of arsenic and antimony in the area abandoned bearing Poproč. (in Slovak). Podzemná voda, 12(2), 132-148.

FL'AKOVÁ, R., ŽENIŠOVÁ, Z., ONDREJKOVÁ, I., KRČMÁŘ, D, GALO, I. 2011. Contamination of natural waters, soils and stream sediments at the abandoned Sb deposits Medzibrod. (in Slovak). Mineralica Acta Slovaca, 43, 419-430.

FL'AKOVÁ, R., ŽENIŠOVÁ, Z., ONDREJKOVÁ, I., KRČMÁŘ, D, GALO, I. 2011. Contamination of antimony and arsenic in a remote bearing Čučma (Slovak Ore Mountains). (in Slovak). Acta Geologica Slovaca, 3(1), 57-74.

HILLER, E., JURKOVIČ, L', KORDIK, J., SLANINKA, I., JANKULAR, M. MAJZLAN, J., GOTTLICHER, J., STEININGER, R. 2009. Arsenic mobility from anthropogenic impoundment sediments - Consequences of contamination to biota, water and sediments, Poša, Eastern Slovakia. Applied Geochemistry, 24 2175-2185. http://dx.doi.org/10.1016/j.apgeochem.2009.09.021.

HUDÁČEK, M., ANTAL, B., ZLOCHA, M. 2000. Impact of mining activities on selected elements of the environment in the Middle Spiš. (in Slovak) Podzemná voda, 6(2), 198-209.

ILAVSKÝ, J., BARLOKOVÁ, A. 2003. Antimony in water and its possible remedies. (in Slovak). Drinking Water (Proceedings of the Work of the Conference with International Participation) Bratislava : SvF STU, 71-79.

JANKULÁR, M., HILLER, E., JURKOVIČ, L', VESELSKÁ, V., MAJZLAN, J. 2009. Arsenic and zinc in impoundment materials and related stream sediments from a polluted area in Eastern Slovakia: distribution, mobility, and water quality. Journal of Hydrology and Hydromechanics, 57(3), 200-211. http://dx.doi.org/10.2478/v10098-009-0019-8.

JUREČKOVÁ, D., TRNOVEC, T., PALKOVIČOVÁ, L', ŠOVČÍKOVÁ, E. KOČAN, A. 2010. Health risk of PCBs in Eastern Slovakia. (in Slovak). Enviromagazín, 2, 14-15.

KOŠICE REGION. 2007. The economic and social development in the Košice Region programming period 2007-2013. Chapter 3.8. Quality of Life (In Slovak) <http://zastupitelstvo.vucke.sk/Dokumenty/2009/232009/dokument1178\%20zast23bod09-4main.pdf>.

KIJOVSKÁ, L. 2013. Ecotoxicology in the water management in Slovakia. (in Slovak). Bratislava : STU, 296 p. ISBN 978-80-227-3944-3.

LANGER, P., KOČAN, A., TAJTÁKOVÁ, M., PETRÍK, J., CHOVANCOVÁ, J., DROBNÁ, B., JURSA, S., RÁDIKOVA, Ž., KOŠKA, J., KŠINANTOVÁ, L., HUČKOVÁ, L., IMRICH, R., WIMMEROVÁ, S., GAŠPERÍKOVÁ, D., YOSHIMASA, SHISHIBA, D., TRNOVEC, T., ŠEBOKOVÁ, E., KLIMEŠ, I. 2007. Fish from industrially polluted freshwater as the main source of organochlorinated pollutants and increased frequency of thyroid disorders and $\begin{array}{lll}\text { dysglycemia. } & \text { Chemosphere, } & \text { S3, }\end{array}$ http://dx.doi.org/10.1016/j.chemosphere.2006.05.132.
RAPANT, S., CICMANOVÁ, S., CVEČKOVÁ, V., DIETZOVÁ, Z. 2001. Assess the potential impact of geochemical environment on population health in Spiš-Gemer Ore: Final Report. (in Slovak). Bratislava : SGIDS. 53 p. <http://www.geology.sk/doc/vs/2000/VS-00_SGUDS.pdf>.

RAPANT, S., CVECKOVÁ, V., DIETZOVÁ, Z., KHUN, M., LETKOVIC̆OVÁ, M. 2009. Environmental and health risks of mining pollution in the Spiš-Gemer Ore Mountain. (in Slovak). Environmental Geochemistry and Health, 31(1), 1116.

RAPANT, S., CVEČKOVÁ, V., DIETZOVÁ, Z., FAJČÍKOVÁ, K. LETKOVIČOVÁ, M., SEDLAKOVA, D. 2011. Effect of geological elements of the environment on the health of the population of the Slovak Republic. (in Slovak). Mineralica Slovaca, 43, 437-448.

SASÁKOVÁ, N., VARGOVÁ, M., ONDRAŠOVIČOVÁ, O., ONDRAŠOVIČ, M., KOTTFEROVÁ, J., SKALICKÁ, M. 2006. Environmental pollution and health risk related to metals in the solid fraction and effluent from waste wate treatment. Bulletin of Environmental Contamination and Toxicology, 76, 671-676 SEA: Report on the Evaluation of the Strategic Document, The waste management Kosice region for the years 2011 - 2015. 88 s. (in Slovak) enviroportal.sk/eia/dokument/175467http://webcache.googleusercontent.com/sea rch?q=cache:kMLw-X31pI4J:www.enviroportal.sk/sk/eia/detail/programodpadoveho-hospodarstva-kosickeho-kraja-na-roky-2011-

$2015+\& \mathrm{~cd}=1 \& \mathrm{hl}=\mathrm{sk} \& \mathrm{ct}=\mathrm{clnk} \& \mathrm{gl}=\mathrm{sk}$

SEA (Slovak Environmental Agency). 2010. Ministry of Environment of the Slovak Republic, Division of Geology and Natural Resources, Slovak Environmental Agency. State environmental relief program burden (2010-2015). (in Slovak). < http://www.environet.sk/user-dataenvironet.sk/gallery/dokumenty/strategicke/narodna/Environ zataze.pdf >

STRNADOVÁ, N., WEYESSA, D., HOLEČEK, M. 2003. Arsenic in drinking waters - the possibility of removing.(in Czech). Drinking Water (Proceedings of the Work of the Conference with International Participation) Bratislava : SvF STU, 64-70.

ŠKULTÉTY, P. 2008. Environmental impacts on the character of the country. (in Slovak). $\langle$ http://www.pulib.sk/elpub2/FM/Kotulic7/pdf doc/skultety.pdf $>$.

ŠUTRIEPKA, M. 2006. Contamination of bottom sediments of selected water reservoirs potentially toxic elements. (in Slovak). 8, <http://www.banskeodpady.sk/files/Michal\%20\%C5\%A0utriepka.pdf> [In Slovak].

TATARKOVÁ, V., HILLER, E., JURKOVIČ, L. 2010. Foreign organic matter in sediments of selected water reservoirs in Slovakia. (in Slovak) Enviromagazín, 4, 11-12.

URSÍNIOVÁ, M. 2011. Risk assessment of arsenic intake from food and water in the SR. (in Slovak). 61 p. <http://www.mpsr.sk/download.php?fID=5115>,

WRI, 2012. Annual Report of the Water Research Institute in 2012. (in Slovak). $<$ http://www.vuvh.sk/download/VS 2012 all.pdf $>$

ZMETÁKOVÁ, Z., ŠALGOVIČOVÁ, D. 2006 b. PCB, environment and a man. (in Slovak). Trendy v potravinárstve, 1(4), 1-4.

ZMETÁKOVÁ, Z., ŠALGOVIČOVÁ, D. 2006. Polychlorinated biphenyls in muscle tissue of freshwater fish in East Slovakia. (in Slovak). Journal of Food and Nutrition Research, 45, 171-178.

ZMETÁKOVÁ, Z., ŠALGOVIČOVÁ, D. 2006 a. The contamination of fish in Eastern Slovakia. (in Slovak). Enviromagazin, 2(8), 22-23.

ŽENIŠOVÁ, Z., FLAKOVÁ, R., JAŠOVÁ, Z., CICMANOVÁ, S. 2009 Antimony and arsenic in waters affected by mining activities in selected areas of Slovakia. (in Slovak). Podzemná voda, 15(1), 100-117. 